\title{
STRUCTURE-ACTIVITY RELATIONSHIP STUDIES ON 4"-O-ACYLTYLOSIN DERIVATIVES: SIGNIFICANCE OF THEIR 23-O-MYCINOSYL AND \\ 4"-O-ACYL MOIETIES IN ANTIMICROBIAL ACTIVITY AGAINST MACROLIDE-RESISTANT MICROBES
}

\author{
Kohki Kiyoshima, Michiko Sakamoto, Hideo Nomura, Takeo Yoshioka \\ and RoKuro OKAMOTO \\ Sanraku Inc., Central Research Laboratories, \\ 4-9-1 Johnan, Fujisawa 251, Japan
}

Tsutomu Sawa, Hiroshi Naganawa and Tomio Takeuchi

Institute of Microbial Chemistry,

3-14-23 Kamiosaki, Shinagawa-ku, Tokyo 141, Japan

(Received for publication June 20,1989)

\begin{abstract}
Essential roles for both the 23- $O$-mycinosyl and $4^{\prime \prime}-O$-acyl moieties of $4^{\prime \prime}$ - $O$-acyltylosin derivatives in the expression of antimicrobial activity against multiple macrolide-resistant strains of Staphylococci and mycoplasmas were demonstrated by in vitro comparison of the MICs of erythromycin, josamycin, tylosin and its 3-and 4"-O-acyl derivatives, demycinosyltylosin (DMT) and its 3- and 4"-O-acyl derivatives and 23-modified 3-O-acetyl-4"-O-isovaleryl-DMT derivatives.
\end{abstract}

In previous papers ${ }^{1 \sim 3)}$, we reported that a variety of tylosin derivatives, which were prepared using chemical and biological methods, were screened for antimicrobial activities against multiple macrolide-resistant clinical isolates of Staphylococci and mycoplasmas. This led to the recent discovery of $4^{\prime \prime}-O$-(4-methoxyphenyl)acetyltylosin (IMC-XV) which is not only active in vitro against multiple macrolide-resistant strains of Staphylococci and mycoplasmas, but also effective in vivo in treatment of experimental animal infections caused by such macrolide-resistant microbes ${ }^{4 \sim 6)}$.

Macrolide-resistant Staphylococci were classified into three major types depending on their inhibition pattern with different macrolide antibiotics according to MiTsUHASHI et al. (type A: all macrolide compounds; type B: erythromycin and oleandomycin; type C: erythromycin $)^{7}$. Structurally, josamycin and tylosin belong to the 16-membered basic macrolide group, and differ in the mycinose moiety, the 4 "-O-acyl side chain and several substituents on the 16-membered aglycone (Fig. 1). It would be interesting to elucidate the reason why $4^{\prime \prime}-O$-acyltylosin derivatives are active against macrolide-resistant microbes, whereas josamycin is inactive.

In the meantime, a blocked mutant (YO-9010) of Streptomyces fradiae was obtained during strain improvement work, which produced demycinosyltylosin (DMT) ${ }^{8,9}$ useful for chemical synthesis of 23-modified tylosin derivatives.

This paper describes the chemical preparation and antimicrobial profiles of 23 -modified $3-O$ acetyl- $4^{\prime \prime}-O$-isovaleryl-DMT derivatives, and the results indicate synergistic roles for the mycinosyl and $4 "-O$-acyl moieties of $4 "$ - $O$-acyltylosin derivatives in the expression of antimicrobial activities against multiple macrolide-resistant strains of Staphylococci and mycoplasmas. 
Fig. 1. Structures of tylosin and related compounds, and josamycin.
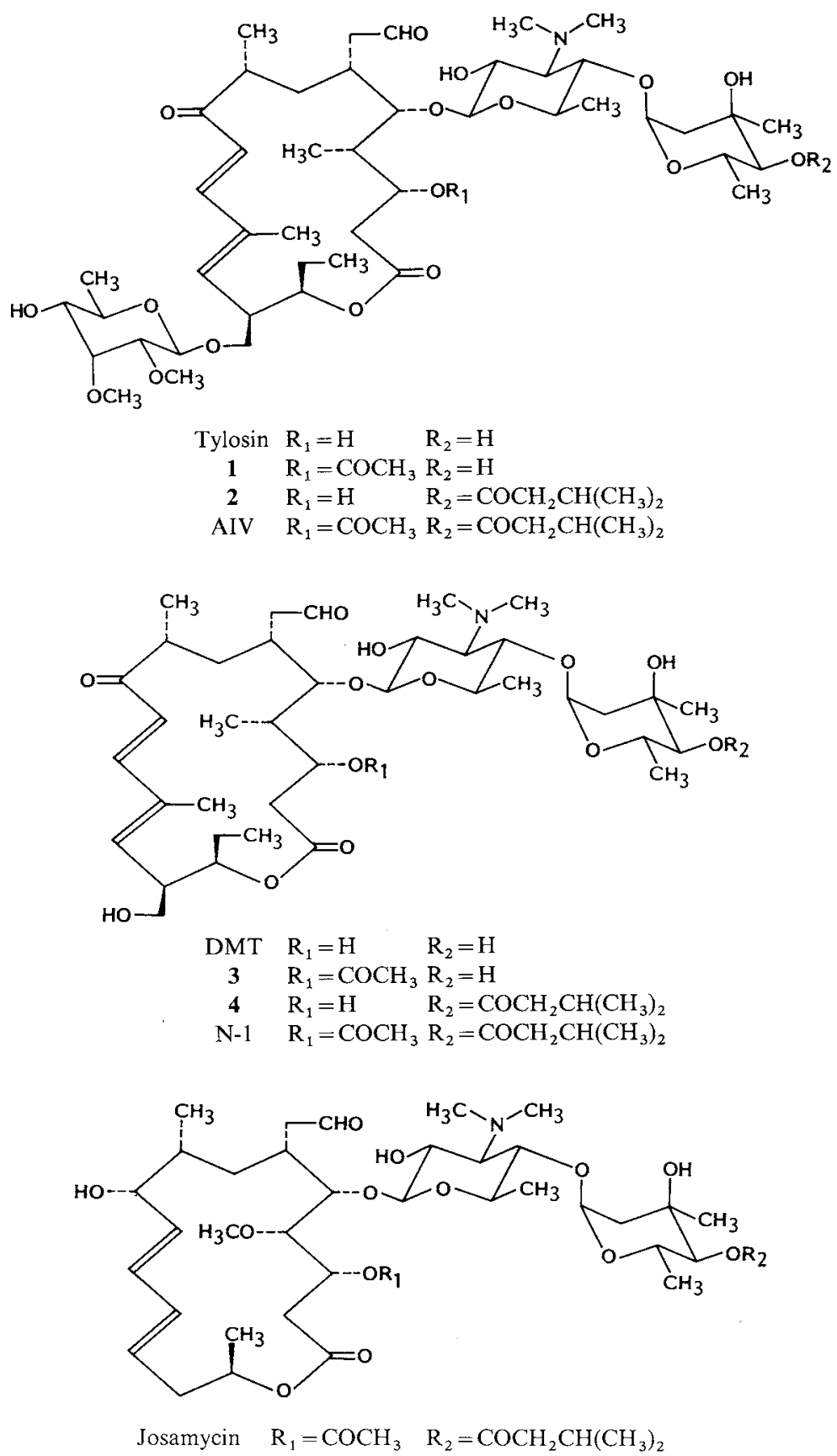

\section{Results and Discussion}

Preparation of 23-Modified N-1 Derivatives

After $S$. fradiae blocked mutant YO-9010 was found to produce a large amount of DMT in fermentation broth $^{9}$, chemical modifications were carried out to develop clinically useful derivatives from DMT. The available information on the structure-activity relationships of tylosin derivatives showed that introduction 
Fig. 2. Structures of 23 -modified N-1 derivatives.

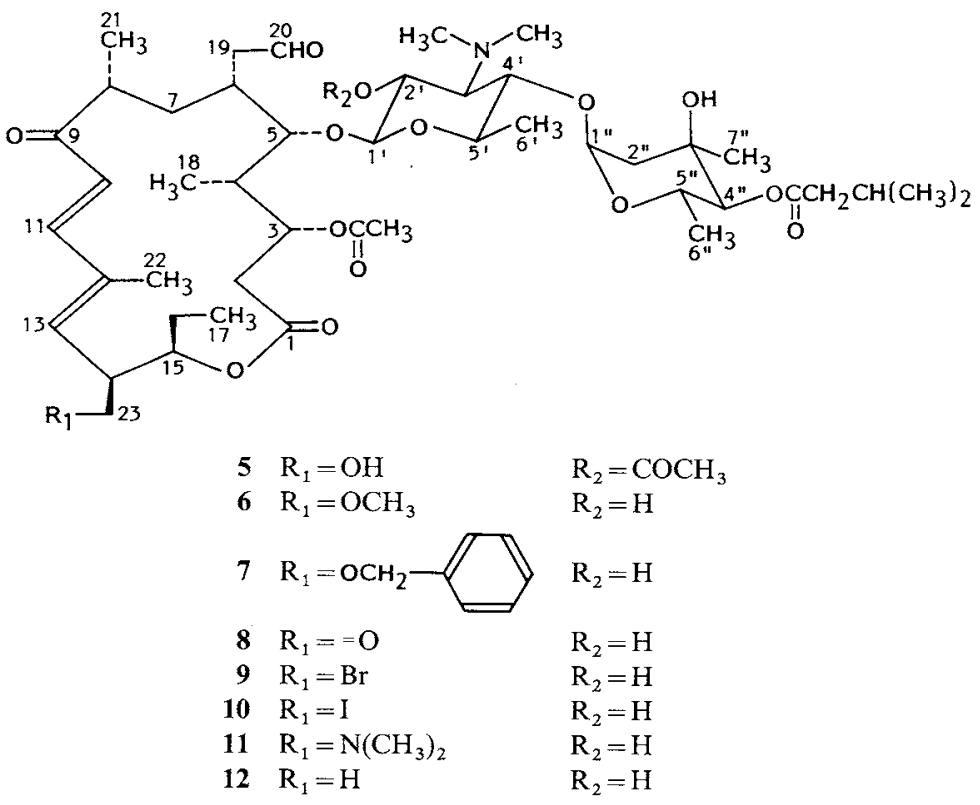

of the $4^{\prime \prime}$-O-acyl group (e.g. 3-O-acetyl-4"-O-isovaleryltylosin, AIV) was apparently useful for increased antimicrobial activity against macrolide-resistant microbes ${ }^{10)}$. Thus 3-O-acetyl-4"-O-isovaleryl-DMT $(\mathrm{N}-1)^{11)}$ which was employed as the starting macrolide compound for the chemical modifications presented here was prepared from DMT via microbial 3,4"-di-O-acylation ${ }^{1)}$. N-1 has three substituent hydroxyl groups, at $\mathrm{C}-23, \mathrm{C}-2^{\prime}$ and $\mathrm{C}-3^{\prime \prime}$. Of these groups, the $2^{\prime}-\mathrm{OH}$ is readily protectable as the acetyl derivative $\left(2^{\prime}-\mathrm{O}\right.$-acetyl- $\left.\mathrm{N}-1,5\right)$, and the $3^{\prime \prime}-\mathrm{OH}$ needs no protection under the reaction conditions used for the $23-$ modifications described in this paper.

23-O-Ether derivatives ( 6 and 7) were prepared from 5 by treatment with neat alkyl halides in the presence of $\mathrm{Ag}_{2} \mathrm{O}$ as acid scavenger. When an aprotic polar solvent such as DMF was used, acetic acid was eliminated from the $\mathrm{C}-2$ and $\mathrm{C}-3$ positions.

23-Deoxy-23-oxo-N-1 (8) was synthesized from 5 with DMSO-dicyclohexylcarbodiimide (DCC) pyridinium trifluoroacetate. As it was rather unstable on silica gel, 8 was partially purified to about $70 \%$ by gel filtration with Sephadex LH-20.

23-Deoxy-23-bromo-N-1 (9), 23-deoxy-23-iodo-N-1 (10) and 23-deoxy-23-dimethylamino-N-1 (11) were obtained using the methods of TANAKA et al. ${ }^{12}$.

The chemical structures of these derivatives and related macrolide compounds were confirmed using ${ }^{1} \mathrm{H}$ NMR spectral analysis.

\section{Antimicrobial Characterization of 23-Modified N-1 Derivatives}

Tables 1 and 2 summarize the antibacterial and antimycoplasmal spectra of 23 -modified N-1 derivatives and related reference macrolide compounds, respectively.

The antibacterial spectra of the new 23-modified $\mathrm{N}-1$ derivatives listed in Table 1 show no substantial differences in antibiotic activity from those of the reference tylosin and DMT derivatives (N-1, DMT, AIV and tylosin), indicating that except for macrolide-resistant strains the mycinose moiety is not involved in the expression of activities against these representative Gram-positive and Gram-negative bacteria. Like 
Table 1. Antibacterial spectra of the 23-modified N-I derivatives and reference macrolide compounds (MIC in $\mu \mathrm{g} / \mathrm{ml}$ ).

\begin{tabular}{|c|c|c|c|c|c|c|c|c|c|c|c|c|c|}
\hline Bacterium & 6 & 7 & 8 & 9 & 10 & 11 & 12 & $\mathrm{~N}-1$ & DMT & AIV & TY & $\mathrm{JM}$ & $\mathrm{EM}$ \\
\hline \multicolumn{14}{|l|}{ Gram-positive bacteria } \\
\hline Bacillus circulans ATCC 9966 & $<0.10$ & $<0.10$ & 0.20 & $<0.10$ & $<0.10$ & 0.10 & $<0.10$ & $<0.10$ & 0.78 & $<0.10$ & 0.20 & 0.20 & 0.10 \\
\hline B. licheniformis ATCC 25972 & $<0.10$ & 0.20 & 0.78 & 0.10 & 0.20 & 0.39 & 0.10 & 0.20 & 0.39 & 0.20 & 0.78 & 0.78 & 12.5 \\
\hline B. subtilis ATCC 6633 & 0.39 & 0.39 & 1.56 & 0.10 & 0.20 & 0.39 & 0.10 & 0.20 & 0.20 & 0.39 & 0.39 & 0.39 & 0.10 \\
\hline $\begin{array}{l}\text { Corynebacterium diphtheriae } \\
\text { ATCC } 11913\end{array}$ & $<0.10$ & $<0.10$ & $<0.10$ & $<0.10$ & $<0.10$ & $<0.10$ & $<0.10$ & $<0.10$ & $<0.10$ & $<0.10$ & $<0.10$ & $<0.10$ & $<0.10$ \\
\hline Micrococcus luteus ATCC 9341 & $<0.10$ & $<0.10$ & $<0.10$ & $<0.10$ & $<0.10$ & $<0.10$ & $<0.10$ & $<0.10$ & $<0.10$ & $<0.10$ & $<0.10$ & $<0.10$ & $<0.10$ \\
\hline $\begin{array}{l}\text { Corynebacterium flavescens } \\
\text { ATCC } 10340\end{array}$ & $<0.10$ & $<0.10$ & $<0.10$ & $<0.10$ & $<0.10$ & $<0.10$ & $<0.10$ & $<0.10$ & $<0.10$ & $<0.10$ & $<0.10$ & $<0.10$ & $<0.10$ \\
\hline Average & 0.15 & 0.17 & 0.47 & 0.10 & 0.13 & 0.20 & 0.10 & 0.13 & 0.28 & 0.17 & 0.28 & 0.28 & 2.17 \\
\hline Staphylococcus aureus FDA 209P & $<0.10$ & $<0.10$ & 0.78 & 0.10 & 0.20 & 0.39 & 0.10 & $<0.10$ & 0.39 & 0.39 & 0.39 & 0.39 & 0.10 \\
\hline S. aureus Smith & $<0.10$ & $<0.10$ & 0.78 & 0.10 & 0.20 & 0.78 & 0.10 & $<0.10$ & 0.39 & 0.39 & 0.39 & 0.20 & $<0.10$ \\
\hline S. aureus Russell & 0.20 & 0.20 & 0.78 & 0.10 & 0.20 & 0.39 & 0.10 & 0.20 & 0.39 & 0.39 & 0.78 & 0.20 & $<0.10$ \\
\hline Staphylococcus sp. S35 & 0.20 & 0.20 & 1.56 & 0.20 & 0.20 & 0.39 & 0.20 & 0.20 & 0.20 & 0.78 & 0.39 & 0.39 & 0.10 \\
\hline Staphylococcus sp. S36 & 0.39 & 0.39 & 3.13 & 0.20 & 0.39 & 0.39 & 0.10 & 0.39 & 1.56 & 0.78 & 1.56 & 0.39 & 0.10 \\
\hline Staphylococcus sp. S37 & 0.20 & 0.39 & 3.13 & 0.20 & 0.20 & 0.39 & 0.20 & 0.20 & 0.78 & 0.78 & 0.78 & 0.20 & $<0.10$ \\
\hline Average & 0.20 & 0.23 & 1.69 & 0.15 & 0.23 & 0.46 & 0.13 & 0.20 & 0.62 & 0.59 & 0.72 & 0.30 & 0.10 \\
\hline \multicolumn{14}{|l|}{ Gram-negative bacteria } \\
\hline Escherichia coli NIHJ & 100 & $>100$ & 100 & $>100$ & $>100$ & 25 & 100 & 50 & 6.25 & 100 & 100 & 100 & 12.5 \\
\hline $\begin{array}{l}\text { Klebsiella pneumoniae } \\
\text { ATCC } 10031\end{array}$ & $>100$ & $>100$ & $>100$ & $>100$ & $>100$ & $>100$ & $>100$ & $>100$ & $>100$ & $>100$ & $>100$ & $>100$ & $>100$ \\
\hline Proteus vulgaris OXCUS & $>100$ & $>100$ & $>100$ & $>100$ & $>100$ & $>100$ & $>100$ & $>100$ & $>100$ & $>100$ & $>100$ & $>100$ & $>100$ \\
\hline Pseudomonas aeruginosa IFO 3445 & $>100$ & $>100$ & $>100$ & $>100$ & $>100$ & $>100$ & $>100$ & $>100$ & 100 & $>100$ & $>100$ & $>100$ & 100 \\
\hline P. fluorescens SOC & $>100$ & $>100$ & $>100$ & $>100$ & $>100$ & $>100$ & $>100$ & $>100$ & $>100$ & $>100$ & $>100$ & $>100$ & 100 \\
\hline $\begin{array}{l}\text { Salmonella gallinarum } \\
\text { ATCC } 9184\end{array}$ & 100 & $>100$ & $>100$ & $>100$ & $>100$ & 50 & $>100$ & 50 & 25 & $>100$ & 100 & 100 & 25 \\
\hline Serratia marcescens IFO 3736 & $>100$ & $>100$ & $>100$ & $>100$ & $>100$ & $>100$ & $>100$ & $>100$ & $>100$ & $>100$ & $>100$ & $>100$ & 100 \\
\hline Shigella sonnei EW 33 & 50 & $>100$ & $>100$ & $>100$ & $>100$ & 25 & 50 & 12.5 & 12.5 & $>100$ & 100 & 100 & 25 \\
\hline
\end{tabular}

TY: Tylosin, JM: josamycin, EM: erythromycin. 
Table 2. Antimycoplasmal spectra of the 23 -modified $\mathrm{N}-1$ derivatives and reference macrolide compounds (MIC in $\mu \mathrm{g} / \mathrm{ml})$.

\begin{tabular}{|c|c|c|c|c|c|c|c|c|c|c|c|c|c|}
\hline Mycoplasma & 6 & 7 & 8 & 9 & 10 & 11 & 12 & N-1 & DMT & AIV & TY & $\mathrm{JM}$ & EM \\
\hline \multicolumn{14}{|l|}{ Macrolide-sensitive } \\
\hline Mycoplasma pneumoniae Mac & 0.0004 & 0.006 & 0.024 & 0.0004 & 0.0008 & 0.003 & 0.0016 & 0.003 & 0.024 & 0.006 & 0.0016 & 0.05 & 0.012 \\
\hline M. gallisepticum $\mathrm{S}-6$ & 0.006 & 0.024 & 0.05 & 0.006 & 0.024 & 0.006 & 0.006 & $<0.0002$ & 0.10 & 0.012 & 0.012 & 0.012 & 0.10 \\
\hline M. gallisepticum KP13 & $<0.0002$ & 0.0016 & 0.012 & $<0.0002$ & 0.0004 & 0.0016 & 0.0008 & 0.0016 & 0.024 & 0.003 & 0.003 & 0.012 & 0.05 \\
\hline Average & 0.0022 & 0.011 & 0.029 & 0.0022 & 0.0084 & 0.0035 & 0.0028 & 0.0016 & 0.049 & 0.007 & 0.0055 & 0.025 & 0.054 \\
\hline \multicolumn{14}{|l|}{ Macrolide-resistant } \\
\hline Mycoplasma gallisepticum $\mathrm{S} 4 \mathrm{~A}$ & 6.25 & 6.25 & 6.25 & 6.25 & 25 & 1.56 & 6.25 & 0.78 & 25 & 0.024 & 0.78 & 6.25 & 100 \\
\hline M. gallisepticum E7 & 6.25 & 6.25 & 6.25 & 6.25 & 12.5 & 1.56 & 6.25 & 0.78 & 25 & 0.05 & 0.78 & 12.5 & 100 \\
\hline M. gallisepticum $\mathrm{E} 11$ & 3.13 & 3.13 & 6.25 & 3.13 & 12.5 & 1.56 & 6.25 & 0.78 & 25 & 0.05 & 0.78 & 25 & 50 \\
\hline M. gallisepticum $\mathrm{E} 40$ & 6.25 & 6.25 & 6.25 & 6.25 & 25 & 1.56 & 6.25 & 0.78 & 25 & 0.05 & 0.78 & 6.25 & 50 \\
\hline M. gallisepticum E57 & 6.25 & 1.56 & 6.25 & 3.13 & 25 & 0.39 & 3.13 & 0.20 & 50 & 0.024 & 0.78 & 50 & 25 \\
\hline M. gallisepticum $\mathrm{E} 103$ & 3.13 & 3.13 & 6.25 & 3.13 & 12.5 & 1.56 & 6.25 & 0.78 & 25 & 0.05 & 0.78 & 12.5 & 25 \\
\hline M. gallisepticum E112 & 3.13 & 6.25 & 6.25 & 6.25 & 25 & 1.56 & 6.25 & 0.78 & 25 & 0.05 & 0.78 & 6.25 & 50 \\
\hline M. gallisepticum A69 & 3.13 & 3.13 & 6.25 & 6.25 & 12.5 & 1.56 & 6.25 & 0.78 & 25 & 0.05 & 0.78 & 3.13 & 50 \\
\hline M. gallisepticum A72 & 3.13 & 3.13 & 6.25 & 6.25 & 12.5 & 1.56 & 6.25 & 0.78 & 25 & 0.05 & 0.39 & 6.25 & 50 \\
\hline M. pulmonis $\mathrm{PG}-22$ & 0.39 & 3.13 & 6.25 & 0.78 & 6.25 & 0.78 & 0.78 & 0.39 & 3.13 & 0.05 & 0.78 & 12.5 & 50 \\
\hline Average & 4.10 & 4.22 & 6.25 & 4.77 & 16.9 & 1.37 & 5.39 & 0.68 & 25 & 0.045 & 0.74 & 14 & 55 \\
\hline
\end{tabular}

TY: Tylosin, JM: josamycin, EM: erythromycin. 
Table 3. Comparative antibacterial activities of the tylosin and demycinosyltylosin derivatives, josamycin and erythromycin (MIC in $\mu \mathrm{g} / \mathrm{ml}$ ).

\begin{tabular}{|c|c|c|c|c|c|c|c|c|c|c|}
\hline Derivative & TY & 1 & 2 & AIV & DMT & 3 & 4 & $\mathrm{~N}-1$ & $\mathrm{JM}$ & $\mathrm{EM}$ \\
\hline Mycinose & + & + & + & + & - & - & - & - & - & \\
\hline 3-O-Acetyl & - & + & - & + & - & + & - & + & + & \\
\hline $4^{\prime \prime}-O$-Isovaleryl & - & - & + & + & - & - & + & + & + & \\
\hline \multicolumn{11}{|l|}{ Macrolide-sensitive } \\
\hline Bacillus circulans ATCC 9966 & 0.20 & 0.20 & $<0.10$ & $<0.10$ & 0.78 & 0.78 & $<0.10$ & $<0.10$ & 0.20 & 0.10 \\
\hline B. licheniformis ATCC 25972 & 0.78 & 0.78 & 0.20 & 0.20 & 0.39 & 0.78 & 0.20 & 0.20 & 0.78 & 12.5 \\
\hline B. subtilis ATCC 6633 & 0.39 & 0.39 & 0.39 & 0.39 & 0.20 & 0.39 & 0.20 & 0.20 & 0.39 & 0.10 \\
\hline Corynebacterium diphtheriae ATCC 11913 & $<0.10$ & $<0.10$ & $<0.10$ & $<0.10$ & $<0.10$ & $<0.10$ & $<0.10$ & $<0.10$ & $<0.10$ & $<0.10$ \\
\hline Micrococcus luteus ATCC 9341 & $<0.10$ & $<0.10$ & $<0.10$ & $<0.10$ & $<0.10$ & $<0.10$ & $<0.10$ & $<0.10$ & $<0.10$ & $<0.10$ \\
\hline Corynebacterium flavescens ATCC 10340 & $<0.10$ & $<0.10$ & $<0.10$ & $<0.10$ & $<0.10$ & $<0.10$ & $<0.10$ & $<0.10$ & $<0.10$ & $<0.10$ \\
\hline Average & 0.28 & 0.28 & 0.17 & 0.17 & 0.28 & 0.38 & 0.13 & 0.13 & 0.28 & 2.17 \\
\hline Staphylococcus aureus FDA 209P & 0.39 & .0 .39 & 0.39 & 0.39 & 0.39 & 0.78 & $<0.10$ & $<0.10$ & 0.39 & 0.10 \\
\hline S. aureus Smith & 0.39 & 0.39 & 0.39 & 0.39 & 0.39 & 0.78 & $<0.10$ & $<0.10$ & 0.20 & $<0.10$ \\
\hline S. aureus Russell & 0.78 & 0.78 & 0.39 & 0.39 & 0.39 & 1.56 & 0.20 & 0.20 & 0.20 & $<0.10$ \\
\hline Staphylococcus sp. S35 & 0.39 & 0.39 & 0.78 & 0.78 & 0.20 & 0.78 & 0.20 & 0.20 & 0.39 & 0.10 \\
\hline Staphylococcus sp. S36 & 1.56 & 1.56 & 0.78 & 0.78 & 1.56 & 3.13 & 0.39 & 0.39 & 0.39 & 0.10 \\
\hline Staphylococcus sp. S37. & 0.78 & 0.78 & 0.78 & 0.78 & 0.78 & 1.56 & 0.39 & 0.20 & 0.20 & $<0.10$ \\
\hline Average & 0.72 & 0.72 & 0.59 & 0.59 & 0.62 & 1.43 & 0.23 & 0.20 & 0.30 & 0.10 \\
\hline \multicolumn{11}{|l|}{ Macrolide-resistant } \\
\hline Staphylococcus aureus MS 8710 & $>100$ & $>100$ & 6.25 & 6.25 & $>100$ & $>100$ & 25 & 25 & $>100$ & $>100$ \\
\hline S. aureus MS 9610 & $>100$ & $>100$ & 25 & 25 & $>100$ & $>100$ & $>100$ & $>100$ & $>100$ & $>100$ \\
\hline S. aureus MS 9937 & 100 & 100 & 6.25 & 6.25 & $>100$ & $>100$ & 50 & 50 & $>100$ & $>100$ \\
\hline S. aureus MS 11588 & $>100$ & $>100$ & 25 & 25 & $>100$ & $>100$ & $>100$ & $>100$ & $>100$ & $>100$ \\
\hline S. aureus MS 11593 & $>100$ & $>100$ & 6.25 & 6.25 & $>100$ & $>100$ & 50 & 50 & $>100$ & $>100$ \\
\hline S. aureus MS 11598 & $>100$ & $>100$ & 1.56 & 1.56 & $>100$ & $>100$ & 12.5 & 12.5 & $>100$ & $>100$ \\
\hline S. aureus MS 11630 & $>100$ & $>100$ & 6.25 & 6.25 & $>100$ & $>100$ & $>100$ & $>100$ & $>100$ & $>100$ \\
\hline S. aureus $\mathbf{S 7}$ & $>100$ & $>100$ & 6.25 & 6.25 & $>100$ & $>100$ & $>100$ & $>100$ & $>100$ & $>100$ \\
\hline S. aureus $\mathrm{S} 9$ & $>100$ & $>100$ & 6.25 & 12.5 & $>100$ & $>100$ & $>100$ & $>100$ & $>100$ & $>100$ \\
\hline S. aureus $\mathrm{S} 12$ & $>100$ & $>100$ & 12.5 & 25 & $>100$ & $>100$ & $>100$ & $>100$ & $>100$ & $>100$ \\
\hline S. aureus $\mathrm{S} 32$ & $>100$ & $>100$ & 12.5 & 12.5 & $>100$ & $>100$ & 100 & 100 & $>100$ & $>100$ \\
\hline Average & $>100$ & $>100$ & 10 & 12 & $>100$ & $>100$ & $\mathbf{M}$ & M & $>100$ & $>100$ \\
\hline
\end{tabular}

TY: Tylosin, JM: josamycin, EM: erythromycin, M: marginal. 
Table 4. Comparative antimycoplasmal activities of the tylosin and demycinosyltylosin derivatives, josamycin and erythromycin (MIC in $\mu \mathrm{g} / \mathrm{ml}$ ).

\begin{tabular}{|c|c|c|c|c|c|c|c|c|c|c|}
\hline Derivative & TY & 1 & 2 & AIV & DMT & 3 & 4 & $\mathrm{~N}-1$ & $\mathrm{JM}$ & EM \\
\hline Mycinose & + & + & + & + & - & - & $\ldots$ & - & - & \\
\hline 3-O-Acetyl & - & + & - & + & - & + & - & + & + & \\
\hline $4^{\prime \prime}-O$-Isovaleryl & - & - & + & + & - & - & + & + & + & \\
\hline \multicolumn{11}{|l|}{ Macrolide-sensitive } \\
\hline Mycoplasma pneumoniae Mac & 0.0016 & 0.0016 & 0.006 & 0.006 & 0.024 & 0.05 & 0.003 & 0.003 & 0.05 & 0.012 \\
\hline$M$. gallisepticum S-6 & 0.012 & 0.012 & 0.012 & 0.012 & 0.10 & 0.10 & $<0.0002$ & $<0.0002$ & 0.012 & 0.10 \\
\hline M. gallisepticum KP13 & 0.003 & 0.003 & 0.003 & 0.003 & 0.024 & 0.05 & 0.0016 & 0.0016 & 0.012 & 0.05 \\
\hline Average & 0.0055 & 0.0055 & 0.007 & 0.007 & 0.049 & 0.067 & 0.0016 & 0.0016 & 0.025 & 0.054 \\
\hline \multicolumn{11}{|l|}{ Macrolide-resistant } \\
\hline Mycoplasma gallisepticum $\mathrm{S} 4 \mathrm{~A}$ & 0.78 & 0.78 & 0.024 & 0.024 & 25 & 25 & 0.78 & 0.78 & 6.25 & 100 \\
\hline M. gallisepticum $\mathrm{E} 7$ & 0.78 & 0.78 & 0.05 & 0.05 & 25 & 50 & 0.78 & 0.78 & 12.5 & 100 \\
\hline M. gallisepticum E11 & 0.78 & 0.78 & 0.024 & 0.05 & 25 & 50 & 0.20 & 0.78 & 25 & 50 \\
\hline M. gallisepticum E40 & 0.78 & 0.78 & 0.024 & 0.05 & 25 & 25 & 0.39 & 0.78 & 6.25 & 50 \\
\hline M. gallisepticum E57 & 0.78 & 0.78 & 0.024 & 0.024 & 50 & 50 & 0.20 & 0.20 & 50 & 25 \\
\hline M. gallisepticum E103 & 0.78 & 0.78 & 0.05 & 0.05 & 25 & 50 & 0.78 & 0.78 & 12.5 & 25 \\
\hline M. gallisepticum E112 & 0.78 & 0.78 & 0.05 & 0.05 & 25 & 25 & 0.78 & 0.78 & 6.25 & 50 \\
\hline M. gallisepticum A69 & 0.78 & 0.78 & 0.05 & 0.05 & 25 & 25 & 0.39 & 0.78 & 3.13 & 50 \\
\hline M. gallisepticum A 72 & 0.39 & 0.78 & 0.05 & 0.05 & 25 & 50 & 0.39 & 0.78 & 6.25 & 50 \\
\hline M. pulmonis $\mathrm{PG}-22$ & 0.78 & 0.78 & 0.024 & 0.05 & 3.13 & 12.5 & 0.20 & 0.39 & 12.5 & 50 \\
\hline Average & 0.74 & 0.78 & 0.037 & 0.045 & 25 & 36 & 0.49 & 0.68 & 14 & 55 \\
\hline
\end{tabular}

TY: Tylosin, JM: josamycin, EM: erythromycin. 
erythromycin, josamycin and tylosin, the new 23-modified N-1 derivatives at $100 \mu \mathrm{g} / \mathrm{ml}$ showed no activity against A type macrolide-resistant Staphylococci ( $c f$. Table 3; data not shown).

Comparative antimycoplasmal profiles of the new N-1 derivatives, N-1, DMT, AIV, tylosin, josamycin and erythromycin (Table 2) suggested that activity against macrolide-sensitive mycoplasma strains was not influenced by the absence of the mycinose moiety, as was the case in bacteria. Even tylosin itself (without the 4"-O-acyl group) was highly active against macrolide-resistant mycoplasmas, whereas DMT was inactive, suggesting an important role for the mycinose moiety in the expression of antibiotic activity against macrolide-resistant mycoplasmas. Among the $\mathrm{N}-1$ derivatives tested, $\mathrm{N}-1$ was the most active, being comparable to tylosin against the resistant mycoplasmas.

\section{Structure-activity Relationships of Tylosin and DMT Derivatives}

Structural comparison (Fig. 1) has revealed that tylosin differs from josamycin in substituents at C-3 (hydroxy in tylosin vs. acetoxy in josamycin), C-4 (methyl vs. methoxy), C-9 (ketone vs. hydroxy), C-12 (methyl vs. hydrogen), C-14 (mycinosyloxymethyl vs. hydrogen), C-15 (ethyl vs. methyl) and C-4" (hydroxy vs. isovaleryloxy $)^{6,13)}$. For closer comparison of antimicrobial activities with josamycin, the 3-O-acetyl and $4 "$ - $O$-isovaleryl series of tylosin and DMT were selected.

Table 3 compares the in vitro antibacterial activities of such tylosin and DMT derivatives (tylosin, 3-O-acetyltylosin (1), 4"-O-isovaleryltylosin (2) and AIV; DMT, 3-O-acetyl-DMT (3), 4"-O-isovaleryl-DMT (4) and $\mathrm{N}-1$ ), josamycin and erythromycin against macrolide-sensitive and -resistant Gram-positive bacteria. As is described above for the 23-modified $\mathrm{N}-1$ derivatives, the removal of mycinose from the tylosin derivatives led to no loss of antibacterial activities against macrolide-sensitive microbes, and rather the decrease in molecular weight seemed to result in slightly improved MICs. In contrast, antibacterial activities against type A macrolide-resistant microbes were drastically reduced by the loss of the mycinose moiety. Although the relative significance of the mycinosyl and $4^{\prime \prime}$-O-acyl moieties in antimicrobial activity against the resistant microbes is not known, it is probable that the coexistence of the mycinose moiety and the 4 "- $O$-isovaleryl side chain contributes to at least an 8 -fold increase in antibiotic activity compared to the derivatives containing no mycinose.

Comparative antimycoplasmal activities of the tylosin and DMT derivatives, josamycin and erythromycin are shown in Table 4. The DMT derivatives were again as active as the tylosin derivatives against the macrolide-sensitive mycoplasmas. Because of the absence of mycinose, DMT and $\mathbf{3}$ were practically inactive against the macrolide-resistant mycoplasmas. The potentiation effect of the mycinose moiety is estimated to be more than 10 times. It is interesting to note that the introduction of the $4 "$ - $O$-isovaleryl side chain resulted in about a 20 -fold improvement in MIC against the macrolide-resistant mycoplasmas. This improvement was more pronounced than the improvement against the macrolideresistant bacteria due to the introduction of the 4 "- $O$-isovaleryl side chain.

In conclusion, the existence of the mycinose moiety seems essential for antimicrobial activities against macrolide-resistant clinical isolates. This should be kept in mind when derivation of tylosin and related compound is attempted.

\section{Experimental}

General Methodology

UV absorption spectra were determined with a Hitachi 200-20 spectrophotometer; optical rotations 
were measured with a Jasco DIP-181 digital polarimeter and field desorption mass spectra (FD-MS) with a Hitachi RMU-7M mass spectrometer. ${ }^{1} \mathrm{H}$ NMR spectra were recorded on a Varian EM-390 spectrometer at $90 \mathrm{MHz}$ using TMS as the internal standard. Silica gel used for column chromatography was Wakogel C-200 (Wako Pure Chemical Industries, Ltd.). Silica gel TLC was carried out on pre-coated Silica gel 60 $\mathrm{F}_{254}$ plates (E. Merck, Darmstadt).

Antibiotic Susceptibility

The data for antibacterial and antimycoplasmal activity are given as MICs in $\mu \mathrm{g} / \mathrm{ml}$. Antibacterial activity was determined using the agar dilution method with Mueller-Hinton agar (Difco Labs.) at $35^{\circ} \mathrm{C}$ for 18 hours with an inoculum size of about $10^{6} \mathrm{cfu} / \mathrm{ml}$. Antimycoplasmal activity was measured using the microtiter procedure in medium containing $1.73 \mathrm{~g}$ of PPLO broth (Eiken Chemical Co., Ltd.), $20 \mathrm{ml}$ fresh horse serum, $10^{5} \mathrm{U}$ potassium benzylpenicillin and $2 \mathrm{mg}$ phenol red per $100 \mathrm{ml}$ water $(\mathrm{pH} 7.8$ before autoclaving). Serial 2-fold dilutions of an antibiotic in the medium were inoculated with an inoculum size of about $10^{6} \mathrm{cfu} / \mathrm{ml}$ of a test mycoplasma and then incubated at $35^{\circ} \mathrm{C}$ for 5 days.

Average MICs were calculated as arithmetic means, under the assumption that $<$ is equal to $=$.

\section{$\mathrm{N}-1$}

$\overline{\mathrm{N}-1}$ was prepared via microbial conversion from DMT or mycaminosyl tylonolide. The method from DMT was similar to that described for the preparation of AIV from tylosin ${ }^{1}$. The method from mycaminosyl tylonolide was as follows.

Growth and fermentation media consisted of glucose $20 \mathrm{~g}$, soybean meal $20 \mathrm{~g}$, yeast extract $1 \mathrm{~g}$, $\mathrm{K}_{2} \mathrm{HPO}_{4} 0.5 \mathrm{~g}$ and $\mathrm{MgSO}_{4} \cdot 7 \mathrm{H}_{2} \mathrm{O} 0.5 \mathrm{~g}$ in 1 liter water and were adjusted to $\mathrm{pH} 7.0$. One loopful of mature spores of strain 8254 (a mutant strain of Streptomyces thermotolerans ATCC 11416) on ISP-2 medium was inoculated into a $500-\mathrm{ml}$ Erlenmeyer flask containing $100 \mathrm{ml}$ of the growth medium and cultured at $37^{\circ} \mathrm{C}$ for 2 days on a rotary shaker at $220 \mathrm{rpm}$. The seed culture $(500 \mathrm{ml})$ was transferred into 100 liters of the fermentation medium in a 200-liter fermentation tank, and cultured aerobically for 24 hours at $37^{\circ} \mathrm{C}$ and $400 \mathrm{rpm}$ (aeration rate: $0.5 \mathrm{v} / \mathrm{v} / \mathrm{m}$ ). Mycaminosyl tylonolide ${ }^{12)}(20 \mathrm{~g})$ dissolved in 1 liter sterile water was added to the culture broth, and was incubated for a further 24 hours under the same conditions.

The bioconversion product was isolated using an established procedure for basic macrolides. The fermentation broth (100 liters) was filtered at $\mathrm{pH} 4.0$, and the filtrate was concentrated to $c a .20$ liters with a reverse osmosis concentrator. The concentrate was adjusted to $\mathrm{pH} 7.0$, and extracted twice with 5 liters each of toluene. The extracts were combined and concentrated to 1 liter under reduced pressure. The toluene solution was back-extracted with 10 liters of $0.1 \mathrm{M}$ citrate buffer $(\mathrm{pH}$ 3.7). The aqueous extract was adjusted to $\mathrm{pH} 7.0$, and extracted again with 1 liter of toluene. The toluene extract was dried over $\mathrm{Na}_{2} \mathrm{SO}_{4}$ and evaporated to dryness, leaving $c a .10 \mathrm{~g}$ of a pale yellow powder. The powder was purified with silica gel column chromatography using a solvent system of benzene-acetone-methanol $(30: 10: 1)$ as eluent. Eluate fractions which showed a single spot of Rf 0.28 on silica gel TLC (benzene-acetone, $2: 1$ ) were combined and evaporated to give $1.5 \mathrm{~g}$ of $\mathrm{N}-1$ as an amorphous white powder. MP $115 \sim 118^{\circ} \mathrm{C}$; $[\alpha]_{\mathrm{D}}^{25}$ $-37.2^{\circ}(c \quad 0.5, \mathrm{MeOH})$; UV $\lambda_{\max }^{\mathrm{MeOH}} \mathrm{nm}(\varepsilon) 283(20,800) ;{ }^{1} \mathrm{H} \mathrm{NMR}\left(\mathrm{CDCl}_{3}\right) \delta 0.97(6 \mathrm{H}, \mathrm{d}, J=6 \mathrm{~Hz}$, $\left.\mathrm{COCH}_{2} \mathrm{CH}\left(\mathrm{CH}_{3}\right)_{2}\right), 1.83(3 \mathrm{H}, \mathrm{s}, 22-\mathrm{H}), 2.10\left(3 \mathrm{H}, \mathrm{s}, 3-\mathrm{OCOCH}_{3}\right), 2.49\left(6 \mathrm{H}, \mathrm{s}, \mathrm{N}\left(\mathrm{CH}_{3}\right)_{2}\right), 3.70(2 \mathrm{H}, 23-\mathrm{H})$, $5.87(1 \mathrm{H}, \mathrm{d}, J=10.5 \mathrm{~Hz}, 13-\mathrm{H}), 6.22(1 \mathrm{H}, \mathrm{d}, J=15.5 \mathrm{~Hz}, 10-\mathrm{H}), 7.34(1 \mathrm{H}, \mathrm{d}, 11-\mathrm{H}), 9.59(1 \mathrm{H}, \mathrm{s}, 20-\mathrm{H})$; FD-MS $m / z 868(\mathrm{M}+\mathrm{H})^{+}$.

\section{3-O-Acetyl-DMT (3)}

3 was prepared via microbial conversion from DMT using a method similar to that described for the preparation of 3-O-acetyltylosin $(\mathbf{1})^{1,14)}$

\section{4"-O-Isovaleryl-DMT (4)}

4 was prepared via microbial conversion from $\mathrm{DMT}^{9)}$ using a method similar to that described for the preparation of $4^{\prime \prime}-O$-isovaleryltylosin $(2)^{1)}$. Rf 0.33 (silica gel TLC; benzene - acetone, $2: 1$ ); $\mathrm{UV} \lambda_{\max }^{\mathrm{MeOH}}$ $\mathrm{nm}(\varepsilon) 282(19,500) ;[\alpha]_{\mathrm{D}}^{25}-45.4^{\circ}(c \quad 0.35, \mathrm{MeOH}) ;{ }^{1} \mathrm{H} \operatorname{NMR}\left(\mathrm{CDCl}_{3}\right) \delta 0.97(6 \mathrm{H}, \mathrm{d}, J=6 \mathrm{~Hz}$, $\left.\mathrm{COCH}_{2} \mathrm{CH}\left(\mathrm{CH}_{3}\right)_{2}\right), 1.81(3 \mathrm{H}, \mathrm{s}, 22-\mathrm{H}), 2.50\left(6 \mathrm{H}, \mathrm{s}, \mathrm{N}\left(\mathrm{CH}_{3}\right)_{2}\right), 4.13\left(1 \mathrm{H}, \mathrm{d}, J_{1^{\prime}, 2^{\prime}}=7.5 \mathrm{~Hz}, 1^{\prime}-\mathrm{H}\right), 4.58(1 \mathrm{H}$, d, $\left.J_{4^{\prime \prime}, 5^{\prime \prime}}=10 \mathrm{~Hz}, 4^{\prime \prime}-\mathrm{H}\right), 5.78\left(1 \mathrm{H}, \mathrm{d}, J_{13,14}=10.5 \mathrm{~Hz}, 13-\mathrm{H}\right), 6.29\left(1 \mathrm{H}, \mathrm{d}, J_{10,11}=15.5 \mathrm{~Hz}, 10-\mathrm{H}\right), 7.29(1 \mathrm{H}$, 
$\mathrm{d}, 11-\mathrm{H}), 9.65(1 \mathrm{H}, \mathrm{s}, 20-\mathrm{H})$; FD-MS $m / z 826(\mathrm{M}+\mathrm{H})^{+}$.

\section{2'-O-Acetyl-N-1 (5)}

Acetic anhydride $(1.1 \mathrm{ml})$ was added dropwise to a solution of $\mathrm{N}-1(5 \mathrm{~g})$ in $50 \mathrm{ml}$ acetone. The mixture was stirred at room temperature for 2 hours. The reaction mixture was poured into ice-water and stirred for 30 minutes. The solution was adjusted to $\mathrm{pH} \mathrm{8.0,} \mathrm{and} \mathrm{then} \mathrm{extracted} \mathrm{with} \mathrm{toluene.} \mathrm{The} \mathrm{toluene} \mathrm{solution}$ was washed with satd sodium bicarbonate and brine, and dried over $\mathrm{Na}_{2} \mathrm{SO}_{4}$. After filtration, the toluene was evaporated off. The residual solid $5(5 \mathrm{~g})$ was used in the next reaction step without further purification. Rf 0.42 (silica gel TLC; benzene-acetone, 2:1); ${ }^{1} \mathrm{H}$ NMR $\left(\mathrm{CDCl}_{3}\right) \delta 0.97(6 \mathrm{H}, \mathrm{d}, J=6 \mathrm{~Hz}$, $\left.\mathrm{COCH}_{2} \mathrm{CH}\left(\mathrm{CH}_{3}\right)_{2}\right), 1.83(3 \mathrm{H}, \mathrm{s}, 22-\mathrm{H}), 2.06\left(3 \mathrm{H}, \mathrm{s}, 2^{\prime}-\mathrm{OCOCH}_{3}\right), 2.10\left(3 \mathrm{H}, \mathrm{s}, 3-\mathrm{OCOCH}_{3}\right), 2.41(6 \mathrm{H}, \mathrm{s}$, $\left.\mathrm{N}\left(\mathrm{CH}_{3}\right)_{2}\right), 3.67(2 \mathrm{H}, 23-\mathrm{H}), 4.21\left(1 \mathrm{H}, \mathrm{d}, J_{1^{\prime}, 2^{\prime}}=7.5 \mathrm{~Hz}, 1^{\prime}-\mathrm{H}\right), 4.57\left(1 \mathrm{H}, \mathrm{d}, J_{4^{\prime \prime}, 5^{\prime \prime}}=10 \mathrm{~Hz}, 4^{\prime \prime}-\mathrm{H}\right), 5.03(1 \mathrm{H}$, $\left.1^{\prime \prime}-\mathrm{H}\right), 5.87\left(1 \mathrm{H}, \mathrm{d}, J_{13,14}=10.5 \mathrm{~Hz}, 13-\mathrm{H}\right), 6.25\left(1 \mathrm{H}, \mathrm{d}, J_{10,11}=15.5 \mathrm{~Hz}, 10-\mathrm{H}\right), 7.34(1 \mathrm{H}, \mathrm{d}, 11-\mathrm{H}), 9.57$ $(1 \mathrm{H}, \mathrm{s}, 20-\mathrm{H})$.

\section{3-O-Methyl-N-1 (6)}

A solution in $4 \mathrm{ml}$ methyl iodide containing $5(0.15 \mathrm{~g})$ and $80 \mathrm{mg}$ of $\mathrm{Ag}_{2} \mathrm{O}$ was heated under reflux for 6 hours. After cooling, the reaction mixture was filtered, and the filtrate was evaporated to dryness. The residue was subjected to purification using silica gel column chromatography (benzene -acetone, $8: 1$ as eluent) to give $46 \mathrm{mg}$ of $23-O$-methyl-2'-O-acetyl-N-1. This material was dissolved in $10 \mathrm{ml}$ methanol, and the solution was refluxed for 7 hours. After the removal of the solvent, the residue was subjected to silica gel column chromatography (benzene - acetone, $4: 1$ as eluent), giving $30 \mathrm{mg}$ of 6 . Rf 0.48 (silica gel TLC; benzene - acetone, 2:1); UV $\lambda_{\max }^{\mathrm{MeOH}} \mathrm{nm}(\varepsilon) 283(19,500) ;[\alpha]_{\mathrm{D}}^{25}-31.8^{\circ}(c 1.08, \mathrm{MeOH}) ;{ }^{1} \mathrm{H}$ NMR $\left(\mathrm{CDCl}_{3}\right) \delta 0.98\left(6 \mathrm{H}, \mathrm{d}, J=6 \mathrm{~Hz}, \mathrm{COCH}_{2} \mathrm{CH}\left(\mathrm{CH}_{3}\right)_{2}\right), 1.81(3 \mathrm{H}, \mathrm{s}, 22-\mathrm{H}), 2.09\left(3 \mathrm{H}, \mathrm{s}, 3-\mathrm{OCOCH}_{3}\right), 2.49$ $\left(6 \mathrm{H}, \mathrm{s}, \mathrm{N}\left(\mathrm{CH}_{3}\right)_{2}\right), 3.28\left(3 \mathrm{H}, \mathrm{s}, 23-\mathrm{OCH}_{3}\right), 3.38(2 \mathrm{H}, 23-\mathrm{H}), 4.13\left(1 \mathrm{H}, \mathrm{d}, J_{1^{\prime}, 2^{\prime}}=7.5 \mathrm{~Hz}, 1^{\prime}-\mathrm{H}\right), 4.58(1 \mathrm{H}$, d, $\left.J_{4^{\prime \prime}, 5^{\prime \prime}}=10 \mathrm{~Hz}, 4^{\prime \prime}-\mathrm{H}\right), 5.84\left(1 \mathrm{H}, \mathrm{d}, J_{13.14}=10.5 \mathrm{~Hz}, 13-\mathrm{H}\right), 6.21\left(1 \mathrm{H}, \mathrm{d}, J_{10.11}=15.5 \mathrm{~Hz}, 10-\mathrm{H}\right), 7.34$ $(1 \mathrm{H}, \mathrm{d}, 11-\mathrm{H}), 9.58(1 \mathrm{H}, \mathrm{s}, 20-\mathrm{H})$; FD-MS $m / z 882(\mathrm{M}+\mathrm{H})^{+}$.

\section{3-O-Benzyl-N-1 (7)}

A solution in $5 \mathrm{ml}$ benzyl bromide containing $5(0.36 \mathrm{~g})$ and $0.15 \mathrm{~g}$ of $\mathrm{Ag}_{2} \mathrm{O}$ was heated at $45^{\circ} \mathrm{C}$ for 6.5 hours. The reaction mixture was treated in a manner similar to the preparation of $23-O$-methyl-N-1 (6), giving $33 \mathrm{mg}$ of $23-O$-benzyl-N-1 (7). Rf 0.56 (silica gel TLC; benzene-acetone, $2: 1$ ); UV $\lambda_{\max }^{\mathrm{MeOH}} \mathrm{nm}$ (c) $\left.282(18,600) ;[\alpha]_{\mathrm{D}}^{25}-25.0^{\circ}(c) 1.63, \mathrm{MeOH}\right) ;{ }^{1} \mathrm{H}$ NMR $\left(\mathrm{CDCl}_{3}\right) \delta 0.99(6 \mathrm{H}, \mathrm{d}, J=6 \mathrm{~Hz}$, $\left.\mathrm{COCH}_{2} \mathrm{CH}\left(\mathrm{CH}_{3}\right)_{2}\right), 1.82(3 \mathrm{H}, \mathrm{s}, 22-\mathrm{H}), 2.11\left(3 \mathrm{H}, \mathrm{s}, 3-\mathrm{OCOCH}_{3}\right), 2.52\left(6 \mathrm{H}, \mathrm{s}, \mathrm{N}\left(\mathrm{CH}_{3}\right)_{2}\right), 3.50(2 \mathrm{H}, 23-\mathrm{H})$, $4.16\left(1 \mathrm{H}, \mathrm{d}, J_{1^{\prime}, 2^{\prime}}=7.5 \mathrm{~Hz}, 1^{\prime}-\mathrm{H}\right), 4.48\left(2 \mathrm{H}, \mathrm{s}, \mathrm{CH}_{2}\right.$-phenyl $), 4.60\left(1 \mathrm{H}, \mathrm{d}, J_{4^{\prime \prime}, 5^{\prime \prime}}=10 \mathrm{~Hz}, 4^{\prime \prime}-\mathrm{H}\right), 5.93(1 \mathrm{H}$, d, $\left.J_{13,14}=10.5 \mathrm{~Hz}, 13-\mathrm{H}\right), 6.26\left(1 \mathrm{H}, \mathrm{d}, J_{10,11}=15.5 \mathrm{~Hz}, 10-\mathrm{H}\right), 7.33(5 \mathrm{H}, \mathrm{s}$, phenyl $), 7.41(1 \mathrm{H}, \mathrm{d}, 11-\mathrm{H})$, $9.66(1 \mathrm{H}, \mathrm{s}, 20-\mathrm{H})$; FD-MS $m / z 958(\mathrm{M}+\mathrm{H})^{+}$.

\section{3-Deoxy-23-oxo-N-1 (8)}

Pyridine $(0.1 \mathrm{ml}), 0.012 \mathrm{ml}$ of TFA and $277 \mathrm{mg}$ of DCC were added to $200 \mathrm{mg}$ of 5 in a mixture of $2 \mathrm{ml} \mathrm{DMSO}$ and $1 \mathrm{ml}$ benzene. The reaction mixture was stirred at room temperature for 3 hours and then diluted in $20 \mathrm{ml}$ toluene. The toluene solution was washed three times with $20 \mathrm{ml}$ each of water and once with $20 \mathrm{ml}$ of satd sodium chloride, and dried over $\mathrm{Na}_{2} \mathrm{SO}_{4}$. After filtration, the toluene solution was concentrated to $c a .2 \mathrm{ml}$ and the concentrate was subjected to Sephadex LH-20 gel filtration column chromatography ( $\mathrm{MeOH}$ as eluent), giving $175 \mathrm{mg} 23$-deoxy-23-oxo-2'-O-acetyl-N-1. The compound was dissolved in $10 \mathrm{ml}$ methanol and refluxed for 7 hours. After cooling, the methanol solution was concentrated to $c a .2 \mathrm{ml}$ and the concentrate was subjected to Sephadex LH-20 gel filtration column chromatography $(\mathrm{MeOH}$ as eluent). Fractions containing 23-deoxy-23-oxo-N-1 (8) were combined and concentrated. The solvent was exchanged for ethyl acetate. The concentrated ethyl acetate solution was added dropwise into hexane to give $60 \mathrm{mg}$ of 23-deoxy-23-oxo-N-1 (8) (purity ca. 70\%). Rf 0.40 (silica gel TLC; benzene - acetone, 2: 1); UV $\lambda_{\max }^{\mathrm{MeOH}} \mathrm{nm}(\varepsilon) 283(19,900) ;[\alpha]_{\mathrm{D}}^{25}-35.9^{\circ}(c 1.14, \mathrm{MeOH}) ;{ }^{1} \mathrm{H} \mathrm{NMR}\left(\mathrm{CDCl}_{3}\right) \delta 0.98(6 \mathrm{H}, \mathrm{d}$, $\left.J=6 \mathrm{~Hz}, \mathrm{COCH}_{2} \mathrm{CH}\left(\mathrm{CH}_{3}\right)_{2}\right), 1.88(3 \mathrm{H}, \mathrm{s}, 22-\mathrm{H}), 2.13\left(3 \mathrm{H}, \mathrm{s}, 3-\mathrm{OCOCH}_{3}\right), 2.52\left(6 \mathrm{H}, \mathrm{s}, \mathrm{N}\left(\mathrm{CH}_{3}\right)_{2}\right), 4.15$ $\left(1 \mathrm{H}, \mathrm{d}, J_{1^{\prime}, 2^{\prime}}=7.5 \mathrm{~Hz}, 1^{\prime}-\mathrm{H}\right), 4.59\left(1 \mathrm{H}, \mathrm{d}, J_{4^{\prime \prime}, 5^{\prime \prime}}=10 \mathrm{~Hz}, 4^{\prime \prime}-\mathrm{H}\right), 5.90\left(1 \mathrm{H}, \mathrm{d}, J_{13,14}=10.5 \mathrm{~Hz}, 13-\mathrm{H}\right), 6.30$ $\left(1 \mathrm{H}, \mathrm{d}, J_{10,11}=15.5 \mathrm{~Hz}, 10-\mathrm{H}\right), 7.35(1 \mathrm{H}, \mathrm{d}, 11-\mathrm{H}), 9.59(1 \mathrm{H}, \mathrm{s}, 20-\mathrm{H}), 9.59\left(1 \mathrm{H}, \mathrm{d}, J_{14,23}=2.5 \mathrm{~Hz}, 23-\mathrm{H}\right)$. 


\section{3-Deoxy-23-bromo-N-1 (9)}

A mixture of $0.7 \mathrm{~g} \mathrm{~N}-1,0.64 \mathrm{~g}$ of triphenylphosphine and $0.54 \mathrm{~g}$ of carbon tetrabromide in $15 \mathrm{ml}$ of pyridine was stirred at room temperature for 30 minutes. The reaction mixture was poured into $100 \mathrm{ml}$ of toluene, washed with satd sodium bicarbonate and satd sodium chloride, and dried over $\mathrm{Na}_{2} \mathrm{SO}_{4}$. After filtration, the toluene solution was evaporated to dryness. The residue was subjected to Sephadex LH-20 gel filtration column chromatography ( $\mathrm{MeOH}$ as eluent) to give $0.62 \mathrm{~g}$ of 23-deoxy-23-bromo- $\mathrm{N}-1$ (9). Rf 0.52 (silica gel TLC; benzene - acetone, 2: 1); UV $\lambda_{\max }^{\mathrm{MeOH}} \mathrm{nm}(\varepsilon) 282(20,000) ;[\alpha]_{\mathrm{D}}^{25}-17.3^{\circ}(c 0.24, \mathrm{MeOH})$; ${ }^{1} \mathrm{H} \mathrm{NMR}\left(\mathrm{CDCl}_{3}\right) \delta 0.98\left(6 \mathrm{H}, \mathrm{d}, J=6 \mathrm{~Hz}, \mathrm{COCH}_{2} \mathrm{CH}\left(\mathrm{CH}_{3}\right)_{2}\right), 1.83(3 \mathrm{H}, \mathrm{s}, 22-\mathrm{H}), 2.10\left(3 \mathrm{H}, \mathrm{s}, 3-\mathrm{OCOCH}_{3}\right)$, $2.54\left(6 \mathrm{H}, \mathrm{s}, \mathrm{N}\left(\mathrm{CH}_{3}\right)_{2}\right), 4.14\left(1 \mathrm{H}, \mathrm{d}, J_{1^{\prime}, 2^{\prime}}=7.5 \mathrm{~Hz}, 1^{\prime}-\mathrm{H}\right), 4.58\left(1 \mathrm{H}, \mathrm{d}, J_{4^{\prime \prime}, 5^{\prime \prime}}=10 \mathrm{~Hz}, 4^{\prime \prime}-\mathrm{H}\right), 5.83(1 \mathrm{H}, \mathrm{d}$, $\left.J_{13,14}=10.5 \mathrm{~Hz}, 13-\mathrm{H}\right), 6.26\left(1 \mathrm{H}, \mathrm{d}, J_{10,11}=15.5 \mathrm{~Hz}, 10-\mathrm{H}\right), 7.36(1 \mathrm{H}, \mathrm{d}, 11-\mathrm{H}), 9.59(1 \mathrm{H}, \mathrm{s}, 20-\mathrm{H}) ;$ FD-MS $m / z 930,932(\mathrm{M}+\mathrm{H})^{+}$.

\section{3-Deoxy-23-iodo-N-1 (10)}

Iodine $(0.32 \mathrm{~g})$ was dissolved in $5 \mathrm{ml}$ of pyridine and added to a mixture of $1.0 \mathrm{~g}$ of $\mathrm{N}-1$ and $0.91 \mathrm{~g}$ of triphenylphosphine in $15 \mathrm{ml}$ of pyridine. After stirred at $0^{\circ} \mathrm{C}$ for 3 hours, the reaction mixture was diluted with $50 \mathrm{ml}$ of toluene, and washed with $0.1 \mathrm{M}$ aqueous sodium thiosulfate so that the excess iodine was decomposed. The toluene layer was then washed with satd sodium bicarbonate and satd sodium chloride, and dried over $\mathrm{Na}_{2} \mathrm{SO}_{4}$. After filtration, the toluene solution was concentrated to dryness. The residue was subjected to silica gel column chromatography (toluene-acetone, $9: 1$ as eluent), giving $0.53 \mathrm{~g}$ of 23-deoxy-23-iodo-N-1 (10). Rf 0.50 (silica gel TLC; benzene - acetone, 2:1); UV $\lambda_{\max }^{\mathrm{MeOH}} \mathrm{nm}(\varepsilon) 282(21,500)$; $[\alpha]_{\mathrm{D}}^{25}+12.4^{\circ}(c 1.74, \mathrm{MeOH}) ;{ }^{1} \mathrm{H} \mathrm{NMR}\left(\mathrm{CDCl}_{3}\right) \delta 0.98\left(6 \mathrm{H}, \mathrm{d}, J=6 \mathrm{~Hz}, \mathrm{COCH}_{2} \mathrm{CH}\left(\mathrm{CH}_{3}\right)_{2}\right), 1.82(3 \mathrm{H}$, s, 22-H), $2.10\left(3 \mathrm{H}, \mathrm{s}, 3-\mathrm{OCOCH}_{3}\right), 2.50\left(6 \mathrm{H}, \mathrm{s}, \mathrm{N}\left(\mathrm{CH}_{3}\right)_{2}\right), 4.13\left(1 \mathrm{H}, \mathrm{d}, J_{1^{\prime}, 2^{\prime}}=7.5 \mathrm{~Hz}, 1^{\prime}-\mathrm{H}\right), 4.57(1 \mathrm{H}, \mathrm{d}$, $\left.J_{4^{\prime \prime}, 5^{\prime \prime}}=10 \mathrm{~Hz}, 4^{\prime \prime}-\mathrm{H}\right), 5.73\left(1 \mathrm{H}, \mathrm{d}, J_{13,14}=10.5 \mathrm{~Hz}, 13-\mathrm{H}\right), 6.30\left(1 \mathrm{H}, \mathrm{d}, J_{10,11}=15.5 \mathrm{~Hz}, 10-\mathrm{H}\right), 7.38(1 \mathrm{H}$, d, 11-H), $9.62(1 \mathrm{H}, \mathrm{s}, 20-\mathrm{H})$; FD-MS $m / z 978(\mathrm{M}+\mathrm{H})^{+}$.

\section{3-Deoxy-23-dimethylamino-N-1 (11)}

Dimethylamine in acetonitrile $(0.77 \mathrm{~m} 1,4.22 \mathrm{M})$ was added to $318 \mathrm{mg}$ of 23 -deoxy-23-iodo- $\mathrm{N}-1$ (10) in $7 \mathrm{ml}$ of acetonitrile, and the mixture was stirred at $80^{\circ} \mathrm{C}$ for 30 minutes. After cooling, the solvent was removed by evaporation. The residue was dissolved in $\mathrm{CHCl}_{3}$. The solution was washed with satd sodium bicarbonate and satd sodium chloride, and dried over $\mathrm{Na}_{2} \mathrm{SO}_{4}$. After filtration, the chloroform solution was evaporated to dryness. The residue was subjected to silica gel column chromatography $\left(\mathrm{CHCl}_{3}-\mathrm{MeOH}\right.$, $30: 1$ as eluent), giving $100 \mathrm{mg}$ of 11. Rf 0.44 (silica gel TLC; $\mathrm{CHCl}_{3}-\mathrm{MeOH}, 7: 1$ ); UV $\lambda_{\max }^{\mathrm{MeOH}} \mathrm{nm}(\varepsilon) 283$ $(20,900) ;[\alpha]_{\mathrm{D}}^{25} 0^{\circ}(c 1.66, \mathrm{MeOH}) ;{ }^{1} \mathrm{H}$ NMR $\left(\mathrm{CDCl}_{3}\right) \delta 0.97\left(6 \mathrm{H}, \mathrm{d}, J=6 \mathrm{~Hz}, \mathrm{COCH}_{2} \mathrm{CH}\left(\mathrm{CH}_{3}\right)_{2}\right), 1.81$ $(3 \mathrm{H}, \mathrm{s}, 22-\mathrm{H}), 2.09\left(3 \mathrm{H}, \mathrm{s}, 3-\mathrm{OCOCH}_{3}\right), 2.17\left(6 \mathrm{H}, \mathrm{s}, 23-\mathrm{N}\left(\mathrm{CH}_{3}\right)_{2}\right), 2.49\left(6 \mathrm{H}, \mathrm{s}, 3-\mathrm{N}\left(\mathrm{CH}_{3}\right)_{2}\right), 4.11(1 \mathrm{H}, \mathrm{d}$, $\left.J_{1^{\prime}, 2^{\prime}}=7.5 \mathrm{~Hz}, 1^{\prime}-\mathrm{H}\right), 4.57\left(1 \mathrm{H}, \mathrm{d}, J_{4^{\prime \prime}, 5^{\prime \prime}}=10 \mathrm{~Hz}, 4^{\prime \prime}-\mathrm{H}\right), 5.82\left(1 \mathrm{H}, \mathrm{d}, J_{13,14}=10.5 \mathrm{~Hz}, 13-\mathrm{H}\right), 6.22(1 \mathrm{H}, \mathrm{d}$, $\left.J_{10,11}=15.5 \mathrm{~Hz}, 10-\mathrm{H}\right), 7.37(1 \mathrm{H}, \mathrm{d}, 11-\mathrm{H}), 9.57(1 \mathrm{H}, \mathrm{s}, 20-\mathrm{H})$; FD-MS $m / z 895(\mathrm{M}+\mathrm{H})^{+}$

\section{3-Deoxy-N-1 (12)}

12 was prepared by microbial conversion from 23-deoxy-23-DMT ${ }^{9)}$ using methods similar to those described for the preparation of $\mathrm{N}-1$. Rf 0.54 (silica gel TLC; benzene-acetone, 2:1); UV $\lambda_{\max }^{\mathrm{MeOH}} \mathrm{nm}$ (e) $\left.284(20,400) ;[\alpha]_{\mathrm{D}}^{25}-38.0^{\circ}(c) 0.82, \mathrm{MeOH}\right) ;{ }^{1} \mathrm{H}$ NMR $\left(\mathrm{CDCl}_{3}\right) \delta 0.98(6 \mathrm{H}, \mathrm{d}, J=6 \mathrm{~Hz}$, $\left.\mathrm{COCH}_{2} \mathrm{CH}\left(\mathrm{CH}_{3}\right)_{2}\right), 1.09\left(3 \mathrm{H}, \mathrm{d}, J_{14,23}=6 \mathrm{~Hz}, 23-\mathrm{H}\right), 1.80(3 \mathrm{H}, \mathrm{s}, 22-\mathrm{H}), 2.10\left(3 \mathrm{H}, \mathrm{s}, 3-\mathrm{OCOCH}_{3}\right), 2.50$ $\left(6 \mathrm{H}, \mathrm{s}, \mathrm{N}\left(\mathrm{CH}_{3}\right)_{2}\right), 4.13\left(1 \mathrm{H}, \mathrm{d}, J_{1^{\prime} .2^{\prime}}=7.5 \mathrm{~Hz}, \mathrm{l}^{\prime}-\mathrm{H}\right), 4.58\left(1 \mathrm{H}, \mathrm{d}, J_{4^{\prime \prime}, 5^{\prime \prime}}=10 \mathrm{~Hz}, 4^{\prime \prime}-\mathrm{H}\right), 5.73(1 \mathrm{H}, \mathrm{d}$, $\left.J_{13,14}=10.5 \mathrm{~Hz}, 13-\mathrm{H}\right), 6.19\left(1 \mathrm{H}, \mathrm{d}, J_{10,11}=15.5 \mathrm{~Hz}, 10-\mathrm{H}\right), 7.33(1 \mathrm{H}, \mathrm{d}, 11-\mathrm{H}), 9.60(1 \mathrm{H}, \mathrm{s}, 20-\mathrm{H}) ;$ FD-MS $m / z 852(\mathrm{M}+\mathrm{H})^{+}$.

\section{References}

1) Okamoto, R.; T. Fukumoto, H. Nomura, K. Kiyoshima, K. Nakamura, A. Takamatsu, H. Naganawa, T. TAKEUCHI \& H. UMEZAWA; Physico-chemical properties of new acyl derivatives of tylosin produced by microbial transformation. J. Antibiotics 33: 1300 1308, 1980

2) Tsuchiya, M.; M. Hamada, T. Takeuchi, H. Umezawa, K. Yamamoto, H. Tanaka, K. Kiyoshima, S. Mori \& R. Окамото: Studies of tylosin derivatives effective against macrolide-resistant strains: Synthesis and structure-activity relationships. J. Antibiotics 35: 661 672, 1982 
3) Kiyoshima, K, M. Sakamoto, T. Ishikura, Y. Fukagawa, T. Yoshioka, H. Naganawa, T. Sawa \& T. Takeuchi: Application of dibutyltin oxide method to regioselective acylation and alkylation of tylosin at C-4". Chem. Pharm. Bull. 37: $861 \sim 865,1989$

4) Yoshioka, T.; K. Kiyoshima, M. Maeda, M. Sakamoto, T. Ishikura, Y. Fukagawa, T. Sawa, M. Hamada, H. NAGANAwA \& T. TAKEUCHI: Synthesis and structure-activity studies of new 4 "-O-acyltylosin derivatives of therapeutic interest. J. Antibiotics 41: 1617 1628, 1988

5) Takeuchi, T.; T. Sawa, H. Naganawa, M. Hamada, H. Umezawa, T. Yoshioka, K. Kiyoshima, H. Iguchi, M. Sakamoto, Y. Shimauchi, H. Tone, Y. Fukagawa \& T. Ishikura: 4"-O-(4-Methoxyphenyl)acetyltylosin, a new macrolide derivative of therapeutic importance. J. Antibiotics 40: 1358 1360, 1987

6) Fukagawa, Y; K. Kiyoshima \& T. Yoshioka: A review on macrolide antibiotics: Some recently developed macrolide derivatives of therapeutic interest. Life Chemistry Reports 6: 276 316, 1988

7) Mitsuhashi, S. \& M. Inoue: Chapter 9. Resistance to macrolides and lincomycins. In Antimicrobial Drug Resistance. Ed., L. E. BRYAN, pp. $279 \sim 291$, Academic Press, 1984

8) Kiyoshima, K; K. Takada, M. Yamamoto, K. Kubo, R. Okamoto, Y. Fukagawa, T. Ishikura, H. Naganawa, T. SAWA, T. TAKeUChI \& H. UMEZAWA: New tylosin analogs produced by mutants of Streptomyces fradiae. J. Antibiotics 40: 1123 1130, 1987

9) OKamoto, R.; K. Kryoshima, M. Yamamoto, K. Takada, T. Ohnuki, T. Ishikura, H. Naganawa, K. Tatsuta, T. TAKEUCHI \& H. UMEZAWA: New macrolide antibiotics produced by mutants from Streptomyces fradiae NRRL 2702. J. Antibiotics 35: $921 \sim 924,1982$

10) Okamoto, R.; M. Tsuchiya, H. Nomura, H. Iguchi, K. Kiyoshima, S. Hori, T. Inui, T. Sawa, T. Takeuchi \& H. UMEZAWA: Biological properties of new acyl derivatives of tylosin. J. Antibiotics 33: 1309 1315, 1980

I1) OKamoto, R,; T. Fukumoto, T. INui \& T. TAKeUChi (Sanraku): Macrolide antibiotic N-1 and its manufacturing methods. Jpn. Kokai 43013 ('80), Mar. 26, 1980

12) Tanaka, A.; T. Tsuchiya, Y. OKada, S. Umezawa, M. Hamada \& H. Umezawa: Synthesis of 23-dialkylamino derivatives of mycaminosyl tylonolide and 4'-deoxymycaminosyl tylonolide effective against Gram-negative bacteria. J. Antibiotics 35: 113 116, 1982

13) OMURA, S. \& A. NAKagawa: Chemical and biological studies on 16-membered macrolide antibiotics. J. Antibiotics 28: $401 \sim 433,1975$

14) Kirst, H. A.; M. Debono, K. E. Willard, B. A. Truedell, J. E. Toth, J. R. Turner, D. R. Berry, B. B. Briggs, D. S. Fukuda, V. M. Daupert, A. M. Felty-Duckworth, J. L. OtT \& F. T. Counter: Preparation and evaluation of $3,4^{\prime \prime}$-ester derivatives of 16 -membered macrolide antibiotics related to tylosin. J. Antibiotics 39: $1724 \sim 1735,1986$ 